\title{
Tuku wan mi naku? Proyecto de Difusión del Patrimonio en Video y T.V. Universidad Veracruzana Intercultural
}

\author{
PANELLA, Maurício de Camargo Teixeira ${ }^{1}$
}

\section{RESUMO}

Este trabalho, em forma de diário de campo, objetiva apresentar reflexões sobre alguns dos fundamentos epistemológicos que estruturam a cosmovisão indígena mesoamericana. O processo de criação audiovisual, realizado pelo Proyecto de Difusión del Patrimonio em Video y T.V, junto aos jovens universitários indígenas vinculados à Universidad Veracruzana Intercultural no México, é a experiência que dá suporte para ampliar as discussões pertinentes sobre arte, cartografia social e educação intercultural.

Interculturalidade. Epistemologia Indígena Mesoamericana. Produção Audiovisual.

Tuku wan mi naku? Project for the Dissemination of Heritage in Video and T.V. Veracruzana Intercultural University

\begin{abstract}
This work is intentionally presented as a fieldwork notebook and aims to reflect about some epistemological fundaments that frame the meso-american indigenous cosmovision. The ethnographic experience that supports our discussion on Art, Social Cartography and Intercultural Education is based on a specific process of audio-visual creation led by the Proyecto de Difusión del Patrimonio em Video y $T . V$ with youth indigenous students related to the Universidad Veracruzana Intercultural in México.
\end{abstract}

Interculturality. Meso-american indigenous epistemology. Audio-visual production.

\footnotetext{
${ }^{1}$ Cientista Social e artista multimídia. Doutor em Artes Visuais pela Universidade de Granada Espanha. Coordenador do Grupo de Pesquisa Encontros de Rua- Depto de Arquitetura e Urbanismo da (UFRN). Fundador do Instituto Casadágua. Professor convidado da Universidad Veracruzana Intercultural.
} 
Figura 1. Logo da Universidad Veracrunzana feita com sementes de milho

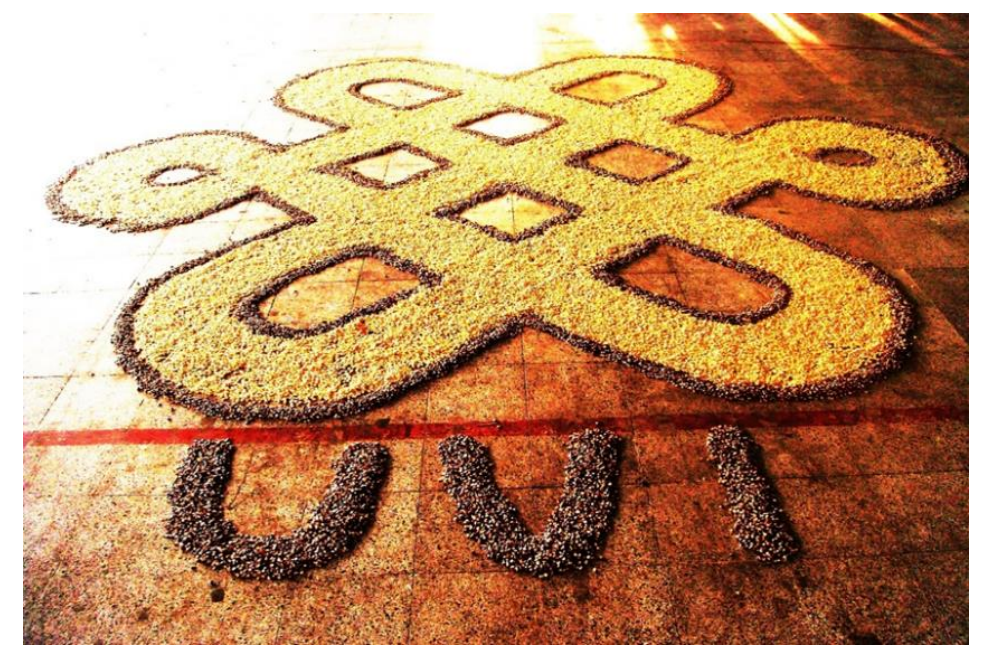

Fonte: O Autor.

\section{Introdução}

A Universidad Veracruzana Intercultural promove o desenvolvimento de programas de ensino superior que contribuam para fortalecer as regiões interculturais do estado de Veracruz, ou seja, aquelas regiões que se reúnem por razões históricas grupos humanos pertencentes aos descendentes dos povos indígenas originários do Estado de Veracruz e também de outros povos indígenas de outros estados da república; assim como grupos e indivíduos vindos de outros países que também decidiram viver no mesmo território.

Entre seus objetivos também está a promoção de processos de geração de conhecimento dos povos das regiões interculturais através da formação de profissionais e intelectuais comprometidos com o desenvolvimento econômico e cultural na comunidade, regional e nacional, cujas atividades contribuam para a promoção de um processo de revalorização e revitalização das línguas e culturas indígenas tendo como fim formar profissionais que atendam às demandas da sociedade em suas regiões de origem e do Estado em programas acadêmicos gerais, transdisciplinares de uma perspectiva intercultural.

A Universidad Veracruzana Intercultural (UVI) nasce da ideia de criar uma universidade que atenda as comunidades que estiveram longe das oportunidades de ensino superior para os planos educacionais de acordo com o contexto das populações. Assim surgiu a Licenciatura em Gestão de Desenvolvimento Intercultural (LGID). Este grau é oferecido nas sedes regionais: Huasteca, Totonacapan, Grandes Montanhas e Selvas, sendo a sede central na cidade de Xalapa, conhecida como Casa UVI. 


\section{Audiovisual como processo de pesquisa e como método pedagógico criativo em direção à educação patrimonial e intercultural}

Fui contratado para trabalhar nas quatro sedes da UVI com o objetivo de criar obras audiovisuais junto aos alunos do curso de Gestão em Desenvolvimento Intercultural que desenvolviam seus trabalhos focados na área da Comunicação. A aventura era tremenda, pois a UVI era uma entidade recém-criada como um braço da Universidad Veracruzana. Entrei para fazer parte de um grupo de profissionais que apenas iniciavam suas atividades nas sedes onde a UVI atua. Nos anos em que trabalhei nesta Universidade nem sequer os Campus estavam construídos e dávamos aula em centros sociais e espaços comunitários das comunidades que recebem os jovens de tantas outras localidades.

A Universidad Veracruazana Intercultural é um projeto audacioso e arrojado. Quando me lancei para trabalhar nas sedes da UVI não imaginava o que poderia encontrar, o que poderia viver. Quando fechei meu contrato, me haviam direcionado para ficar uma semana em cada sede dando o curso que me exigiam. Mas eu vinha de processos construtivos junto a comunidades que haviam tardado mais de ano. Eu sabia que o trabalho de construção criativa coletiva em comunidade não se abre da noite para o dia. Sempre soube que o trabalho em comunidade é um trabalho de escuta sensível, de contato sincero. Sempre soube que o trabalho em comunidade é como uma flor que se desabrocha, pétala por pétala. Então, sugeri ao meu coordenador, Raciel Damion, que eu necessitaria permanecer um mês em cada sede.

A diversidade cultural que se encontra nas sedes é muito grande. Há sedes aonde encontramos mais de uma etnia. Há sedes onde os alunos falam mais de quatro línguas originárias, com suas quatro cosmovisões específicas. Cada sede está localizada em uma região do Estado de Veracruz. Cada região tem um ecossistema diferente do outro, um clima diferente.

Minha atuação nas sedes ocorreu em duas etapas distintas. Numa primeira eu percorri todas as sedes permanecendo um mês em cada uma delas. Iniciei em setembro na Sede Totonacapan, em outubro fui para a Huasteca, em novembro fui para Grandes Montanhas e em dezembro fui para Selvas. A cada lugar que eu passava, na sede seguinte já me aguardavam.

Eu estava trabalhando formando os jovens universitários da primeira geração desta Universidade. Havia muita coisa ainda para aprender, para descobrir no caminhar do projeto UVI. Eu me senti muito agraciado por pertencer àquela família. Eu vinha de outro país, estava contratado e tinha à minha disposição profissionais e equipamentos. Era realmente uma situação ímpar para um antropólogo artista. 
Figura 2. Meu documento/contrato de trabalho expedido pelas autoridades mexicanas

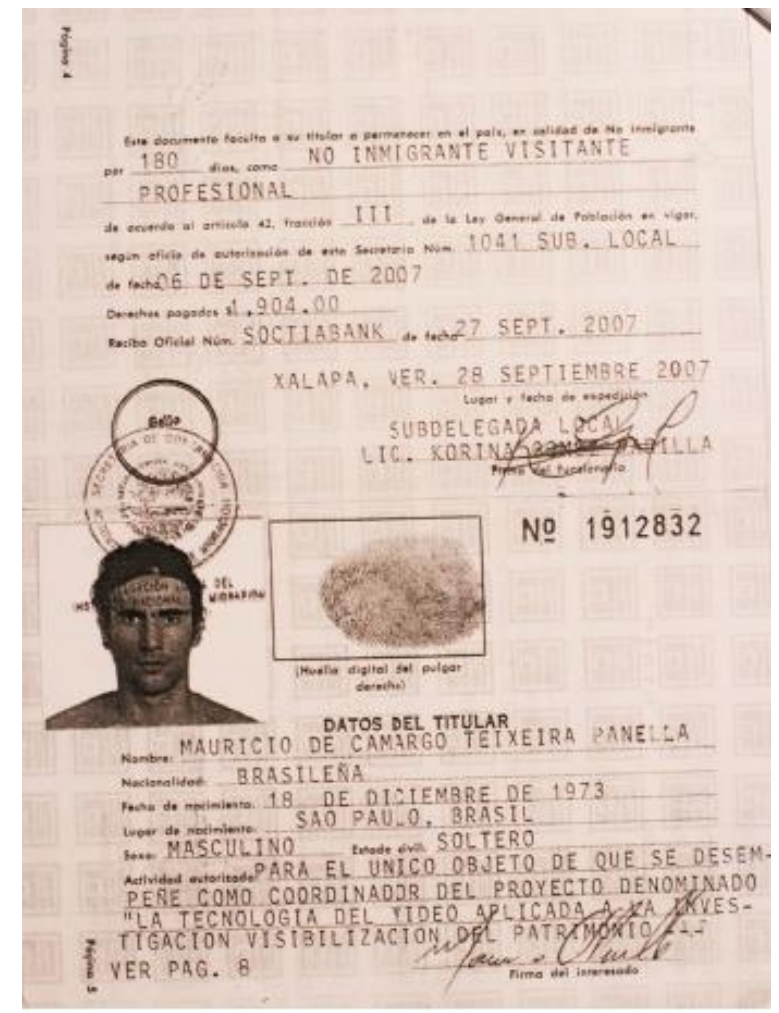

Fonte: O Autor.

Figura 3. Evento da UVI na Sede Huasteca

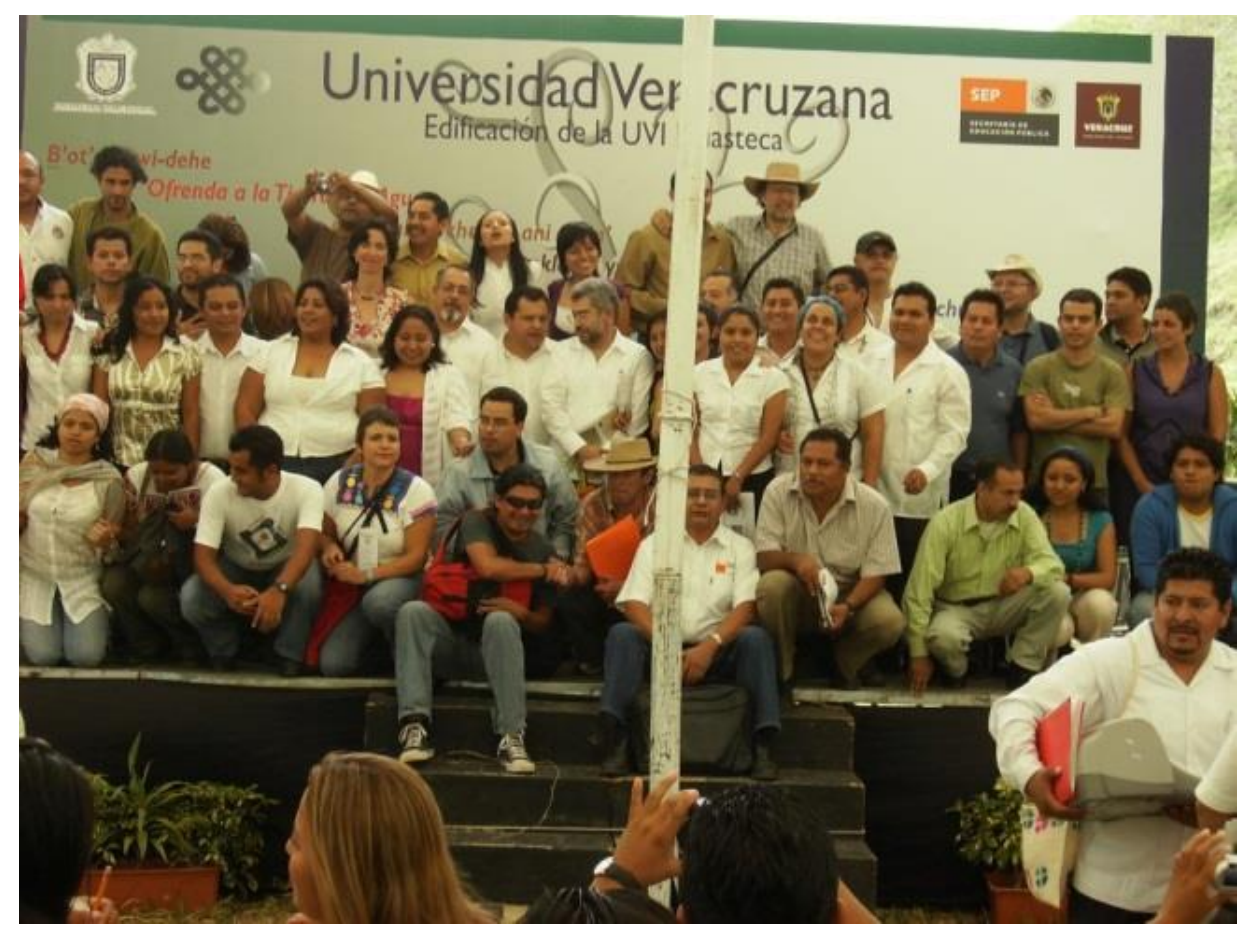

Fonte: Arquivo UVI. 
Figura 4. Mapa da República Mexicana

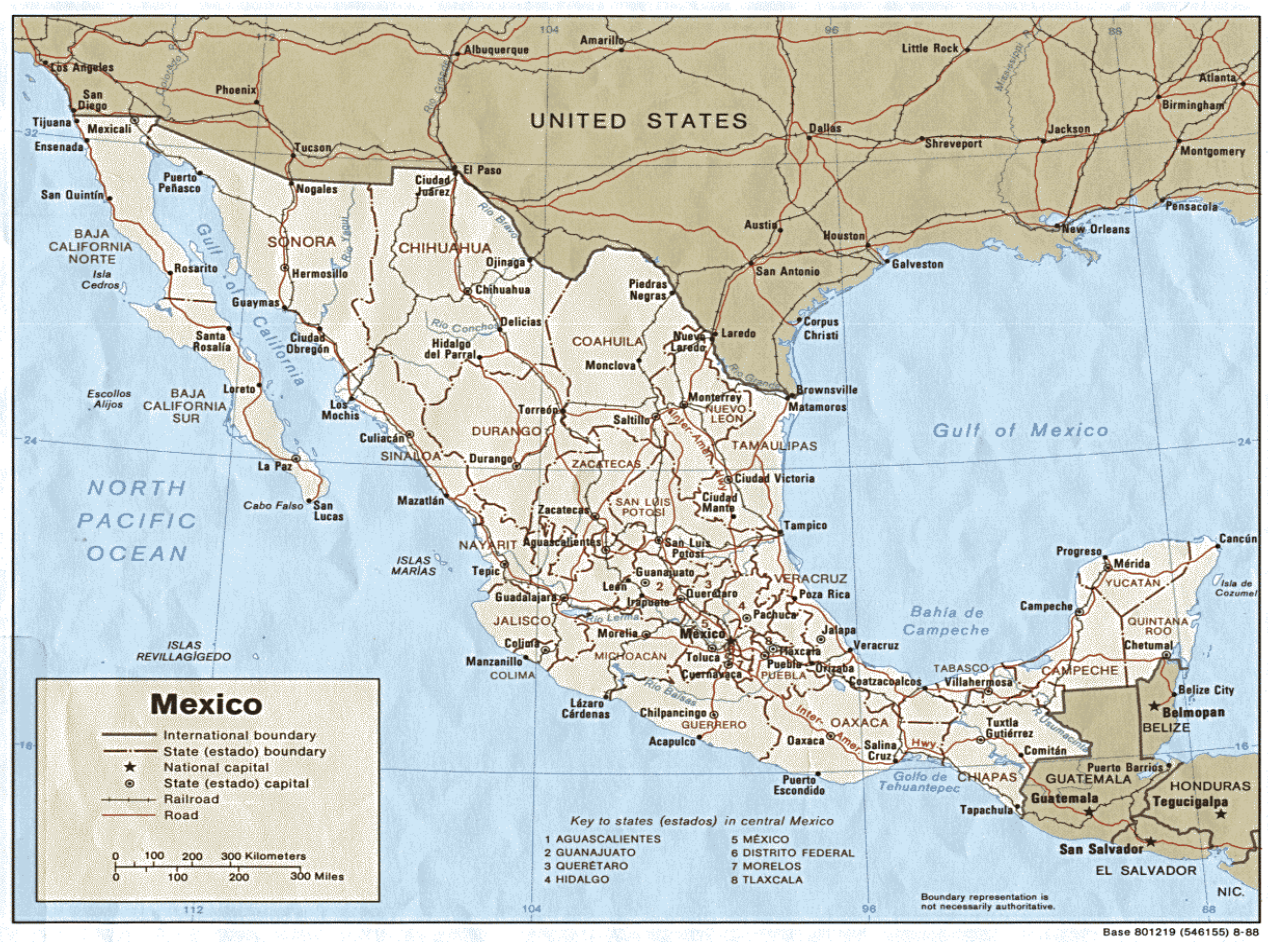

Fonte: www.guiageo-americas.com

Figura 5. Mapa do Estado de Veracruz - México

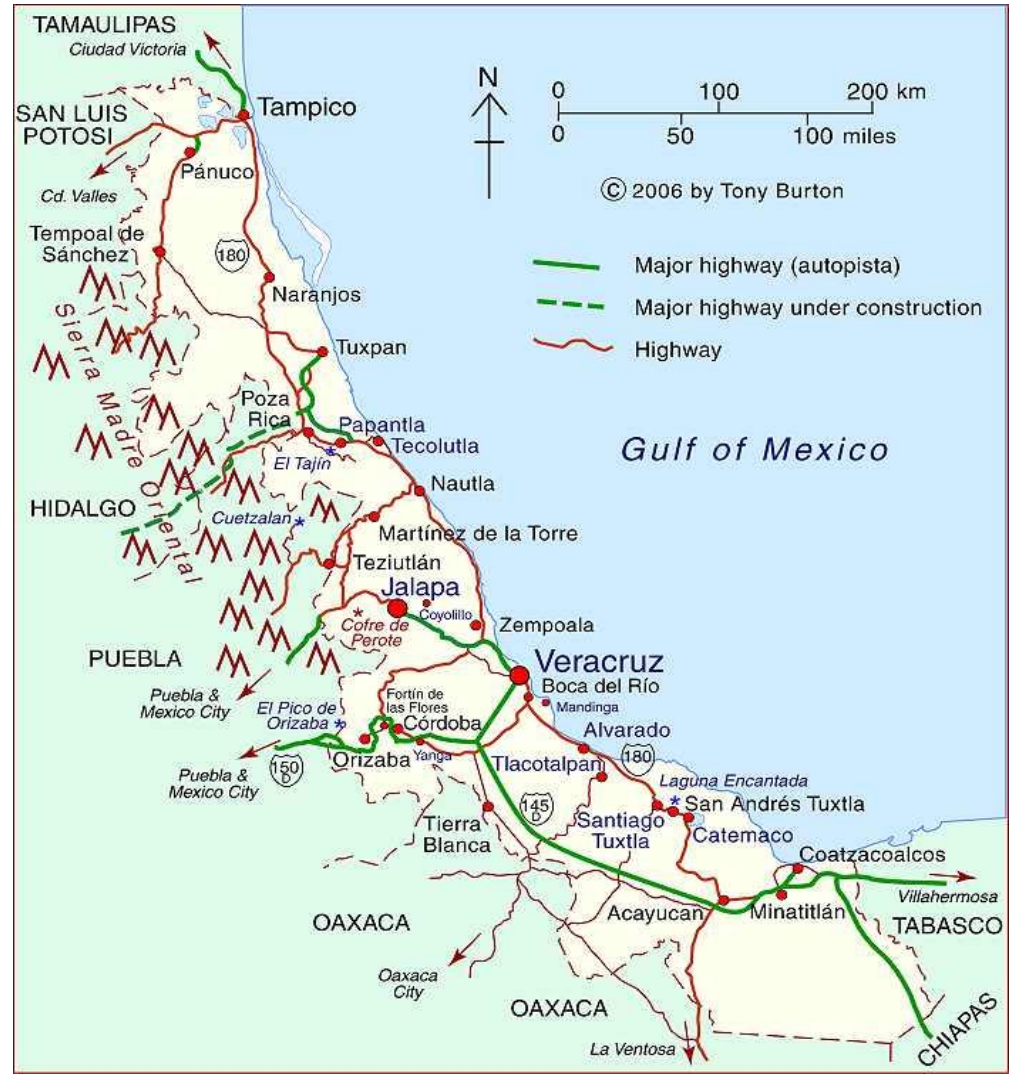

Fonte: www.mexconnect.com 


\section{Sedes da Universidad Veracruzana Intercultural}

$\mathrm{Na}$ Universidad Veracruzana Intercultural existem quatro sedes espalhadas pelo Estado de Veracruz.

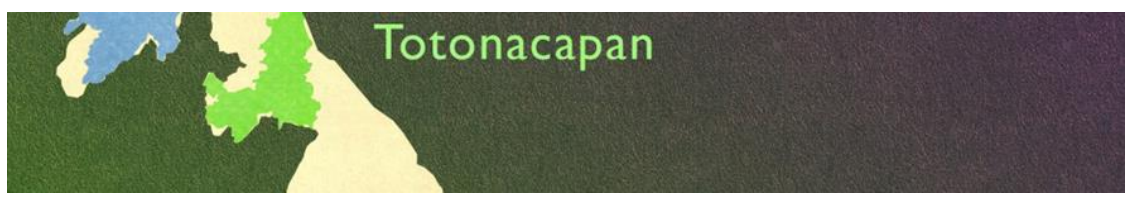

Figura 6. Foto aérea região Espinal

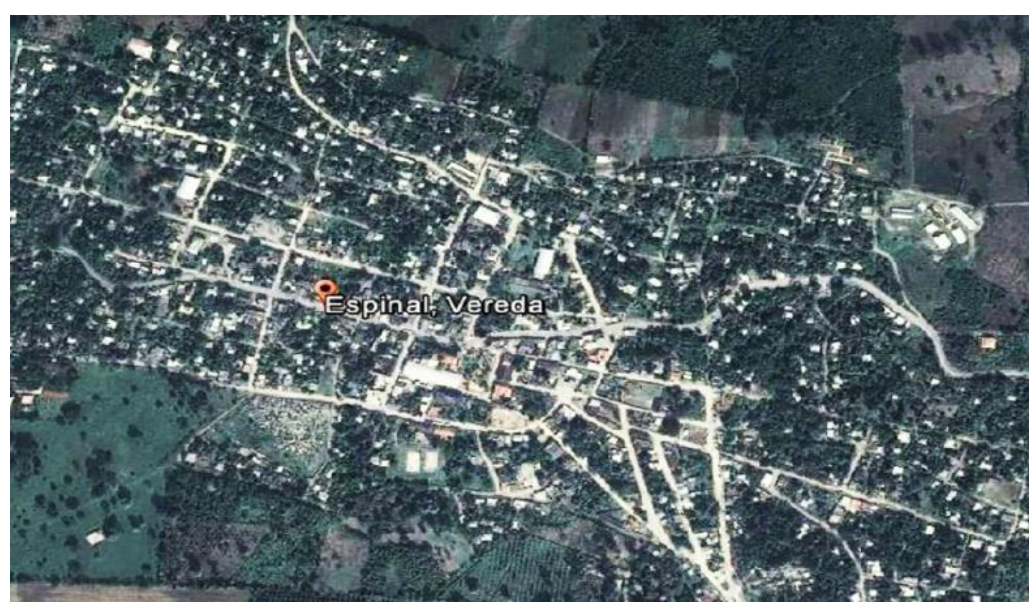

Fonte: Google Earth.

\section{Totonacapan}

Esta é a sede que atende alunos dos municípios de Cazones de Herrera, Espinal, Zozocolco de Hidalgo, Coxquihui, Chumatlán, Mecatlán, Filomeno Mata,Coahuitlán, Papantla, Coyutla e outros municípios veracruzanos e de estados vizinhos dentro da Região Intercultural do Totonacapan.

Iniciamos o "Proyecto de Difusión del Patrimonio en Video y TV" pela região do Totonacapan ${ }^{2}$ com predominância de habitantes originários da cultura totonaca. A sede desta região está situada na pequena cidade de Espinal, recebendo jovens universitários oriundos dos municipios de Cazones de Herrera, Zozocolco de Hidalgo, Coxquihui, Chumatlán, Mecatlán, Filomeno Mata, Coahuitlán, Papantla, Coyutla e outros municípios veracruzanos e também de estados vizinhos dentro da Região Intercultural do Totonacapan.

\footnotetext{
${ }^{2}$ Totonacapan: Totonacapan es el nombre de una región mexicana que se sitúa fundamentalmente no norte do Estado de Veracruz.
} 
O coordenador da área de comunicação nesta sede era naquela ocasião o antropólogo e professor Juan Pablo Zebadua. Como solicitado em meu contrato, ficaria nas imediações da sede, e a coordenação da UVI então me direcionou para compartilhar a casa onde este Professor morava, ocupando um dos quartos. A estrutura da sede era muito básica, ocupávamos salas que a prefeitura nos punha a disposição. Mas o que mais importava ali era o envolvimento quase que familiar que se construiu entre professores, alunos e funcionários.

Totonacapan era minha primeira sede e eu precisava ainda compreender bem o que era a UVI. A direção geral de Xalapa confiava muito em mim e me havia colocado à disposição alguns equipamentos. Aos poucos, nós fomos nos configurando como grupo, como um coletivo que tínhamos como meta comum a produção de um filme. Eles nunca haviam produzido nada. Poucos alunos iniciavam suas práticas. Dois alunos se destacavam, Gonzalo e Éder. Num grupo no qual a maioria dos alunos eram mulheres, estes dois rapazes se destacavam pela iniciativa e disposição. Até mesmo porque um dos temas que mais chamava a atenção nesta sede era a problemática da imigração juvenil masculina. Era comum nos pueblos o número pequeno de jovens do sexo masculino, o que de alguma forma desiquilibrava as famílias e fragilizava algumas tradições. Assim, o papel dos jovens do sexo masculino na UVI era bastante importante para que eles mesmos se dessem conta do problema que o Estado e a República vivia e ainda vive.

Após escutarmos todos os temas decidimos reunir alguns que tinham mais proximidade entre eles para então nos dividirmos em grupos para realizar nossas gravações. O que mais chamava atenção de todos era a possibilidade de termos aulas de campo. Realizamos diversas saídas a campo para gravarmos entrevistas. As vezes nossas saídas eram de dois dias, pois íamos a alguns municípios distantes. Essa estrutura de curso nos aproximou muito, pois dava a possibilidade de sempre estarmos conversando e nos conhecendo. Pouco a pouco fui percebendo que a maioria dos alunos não conhecia os munícipios de seus outros colegas. Cada aluno traçava suas trajetórias cotidianas para a UVI e da UVI para casa, e poucos haviam tido a oportunidade e até mesmo o interesse em ir visitar as comunidades vizinhas.

Nossas práticas realmente se destacavam por esse simples método freiriano de aproximação da realidade cotidiana nossa mesma e de um colega. Os temas escolhidos por cada aluno finalmente eram investigados e reconhecidos pelo grupo todo. E as saídas a campo permitiam que esta aproximação física trouxesse mais sentimento e apropriação com a temática abordada. O método freiriano de investigação-ação participativa finalmente o que faz é trazer uma questão pessoal como uma questão grupal e é este acionar de chave que faz com que uma problemática que pode transparecer muito pessoal e subjetiva tornar-se mais familiar e coletiva. Quando um tema é apropriado pelo grupo então se pode transformar o olhar ou a interpretação que se tem fixa. O audiovisual realmente cria essa 
possibilidade de releitura de mundo. O equipamento de vídeo, e o posicionamento que ocupa o entrevistador e o câmera faz com que o olhar para o tema abordado deixe de ser considerado algo tão familiar para tornar-se um objeto de pesquisa e de reflexão coletiva. Afinal o produto finalizado há de ser compartilhado e há que se refugar as ideias pré-estabelecidas. Deste modo uma câmera de vídeo bem utilizada é um espelho que pode mostrar o rosto de alguém, a personalidade de uma pessoa, de uma cultura.

O trabalho na região do Totonacapan foi me mostrando dia após dia que os próprios alunos não conheciam o patrimônio da própria região. Assim em um dos encontros em sala de aula pedi que os alunos definissem o que era para eles PATRIMÔNIO e que identificassem alguma manifestação patrimonial em sua comunidade e ou família. Pouco a pouco, cada um foi se dando conta que o que estávamos ali fazendo era um estudo, uma representação deles mesmos e de seus lugares. Nosso projeto tinha essa finalidade, reconhecer e fortalecer a cultura local. E para que houvesse esse reconhecimento cada um tinha que sentir-se fazendo parte de seu lugar. E ao trazermos as narrativas de seus pais, seus avós, seus vizinhos, naturalmente cada um desenvolvia e assumia o pertencimento daquele local.

Com nosso cronograma e nossos destinos pré-estabelecidos, cada grupo de alunos assumia a responsabilidade de agendamento com os entrevistados em sua comunidade. Isto tanto por um lado nos abria as portas para que fossemos bem recebidos e que não surgissem dúvidas de nossos propósitos, como também enaltecia a pessoa que se responsabilizava. Afinal cada um naquela saída a campo assumia a representação de seu lugar. Com essa simples atitude, lográvamos a formação deles como Gestores Interculturais, finalidade máxima que se almeja a UVI.

Foi ficando claro pouco a pouco os papéis que cada aluno ia assumindo no desenvolver de nosso projeto audiovisual. Tínhamos alguns poucos alunos que falavam a língua totonaca. Muitos entendiam, no entanto poucos falavam e esses então pouco a pouco foram assumindo seu papel de tradutores das entrevistas. Outros logo assumiram o papel de câmeras, e a maioria desenvolvia as perguntas para serem realizadas.

Nosso trabalho na região do Totonacapan, por ser o primeiro de todas as sedes abarcou um panorama muito amplo de muitas comunidades. Quisemos tocar os vários temas e as várias comunidades que os alunos estavam pesquisando. Isto foi se transformando no decorrer do projeto nas outras sedes. Mas desde o início o projeto foi muito arrojado no sentido de realizar saídas a campo levando todos os alunos a municípios que chegavam a estar distantes duas horas de Espinal, comunidade sede. A UVI não possuía veículo próprio para realizar estas saídas a 
campo, o que fazia com que nos locomovêssemos de ônibus e pau de arara3. Nas viagens, como responsável, eu me preocupava muito, pois principalmente nos transportes mais simples, como os paus de arara, os alunos iam pendurados para fora das caminhonetes. Era uma grande aventura, mas também um grande risco. Finalmente, essa também foi uma forma de eu conhecer o cotidiano dos alunos, que muitos deles utilizavam esses mesmos transportes todos os dias para ir e vir para a UVI.

Nesta região fizemos algumas viagens marcantes com os alunos. Por fim, três delas proporcionaram a construção do recheio do documentário, que intitulamos? Tuku wan mi naku? Que na língua totonaca quer dizer "Que diz teu coração?". Esta é a saudação cotidiana do povo totonaco quando as pessoas se encontram nas ruas. Não se diz bom dia, nem boa tarde. Não se pergunta se está bem ou como vai. Entre os totonacos o que se quer saber é o que diz o coração de cada um. Acho que esse foi o meu primeiro estranhamento linguístico, se me coloco como Carlos Lenkendorf ao analisar minha estadia com o povo totonaco. Quando em sala de aula trocávamos conhecimentos sobre as diferenças entre as línguas, essa me chamou muito a atenção. O que para eles não significava muito, pois era algo cotidiano.

Figura 7. O vídeo de Tuku wan mi naku

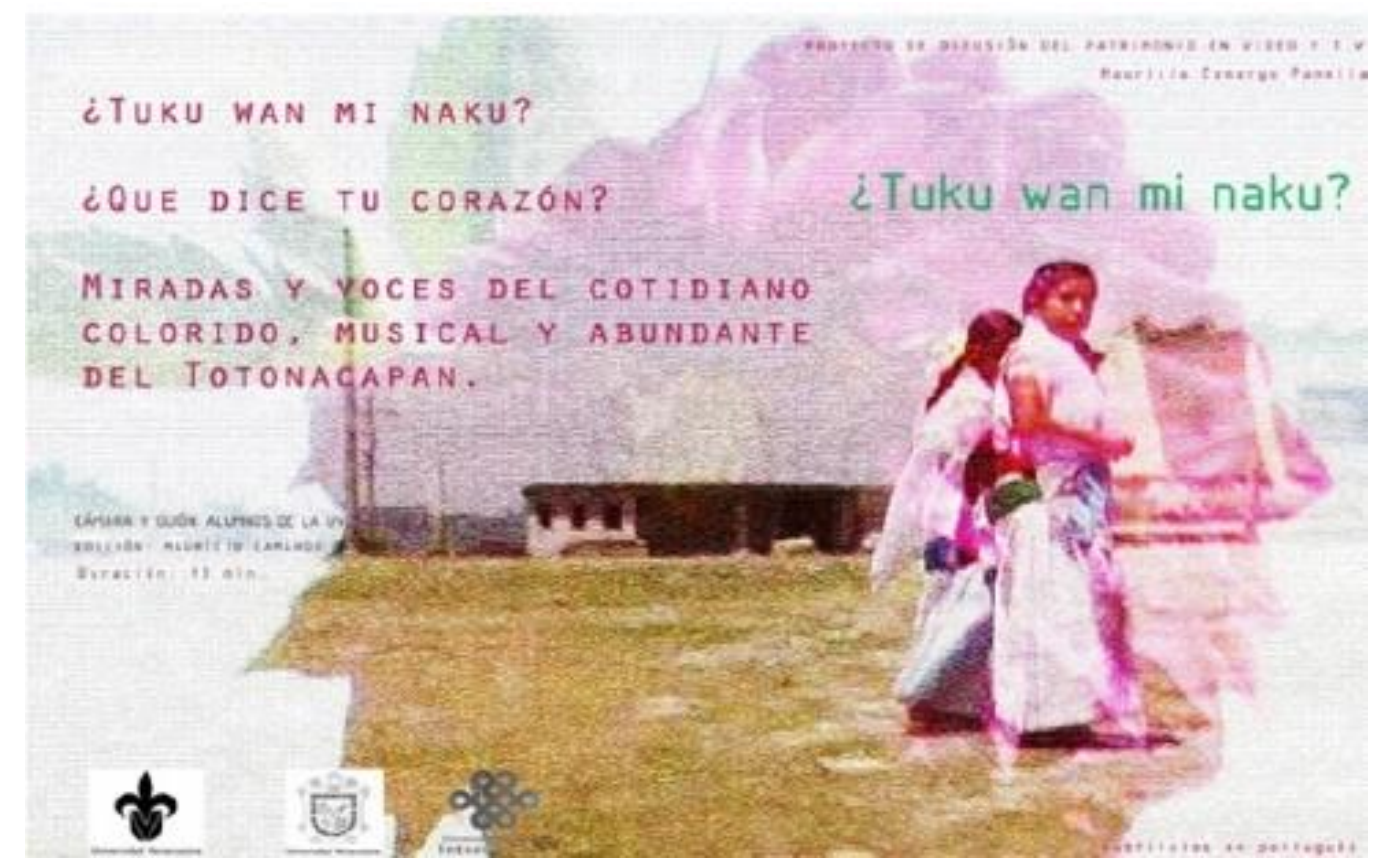

Fonte: Youtube in < https://youtu.be/pudVOI89o0c>

Nossa base era em Espinal, e para compormos nosso filme realizamos saídas para outros municípios. Especificamente, fomos para Coxiquihui, Zozocolco, Coyutla

\footnotetext{
${ }^{3} \mathrm{Pau}$ de arara: Pau de arara é o nome dado a um meio de transporte irregular, e ainda utilizado no Nordeste do Brasil. Consiste em se adaptar caminhões para o transporte de passageiros, constituindo-se em substituto improvisado para os ônibus convencionais.
} 
e Cahuitlán. Em alguns deles havia alunos que moravam, o que nos facilitou muito a composição de um cronograma e agendamento com os entrevistados. As famílias dos alunos sempre nos recebiam muito bem, chegando a algumas vezes até mesmo a dar-nos hospedagem, para mim e para outros alunos que eram de outros municípios.

A produção audiovisual realizada num contexto como este proporciona o exercício de transmutação do olhar cotidiano, costumeiro, a dar uma volta sobre si mesmo. No instante que o pesquisador/diretor de cena/entrevistador assume seu papel como criador de uma nova realidade sobre o tema posto em questão, os sujeitos e as paisagens registradas tomam outra dimensão. $O$ tempo profano é quebrado, posto de lado para que se erga o tempo de criação, o tempo de eternização. Assim, os alunos, apesar de estarem fazendo gravações em locações costumeira, as cenas capturadas tomavam outra importância. Houve muitas declarações sobre este processo de transmutação do sujeito pelo uso da ferramenta audiovisual. $O$ processo se assemelha muito ao processo de análise psicanalítica onde a realidade mencionada, vista, falada e emitida perde o peso e o significado personalizado para então compreender-se a complexidade global da situação. É aberto ao entendimento.

Figura 8. Mapa da região Totonacapan, em azul os municípios visitados

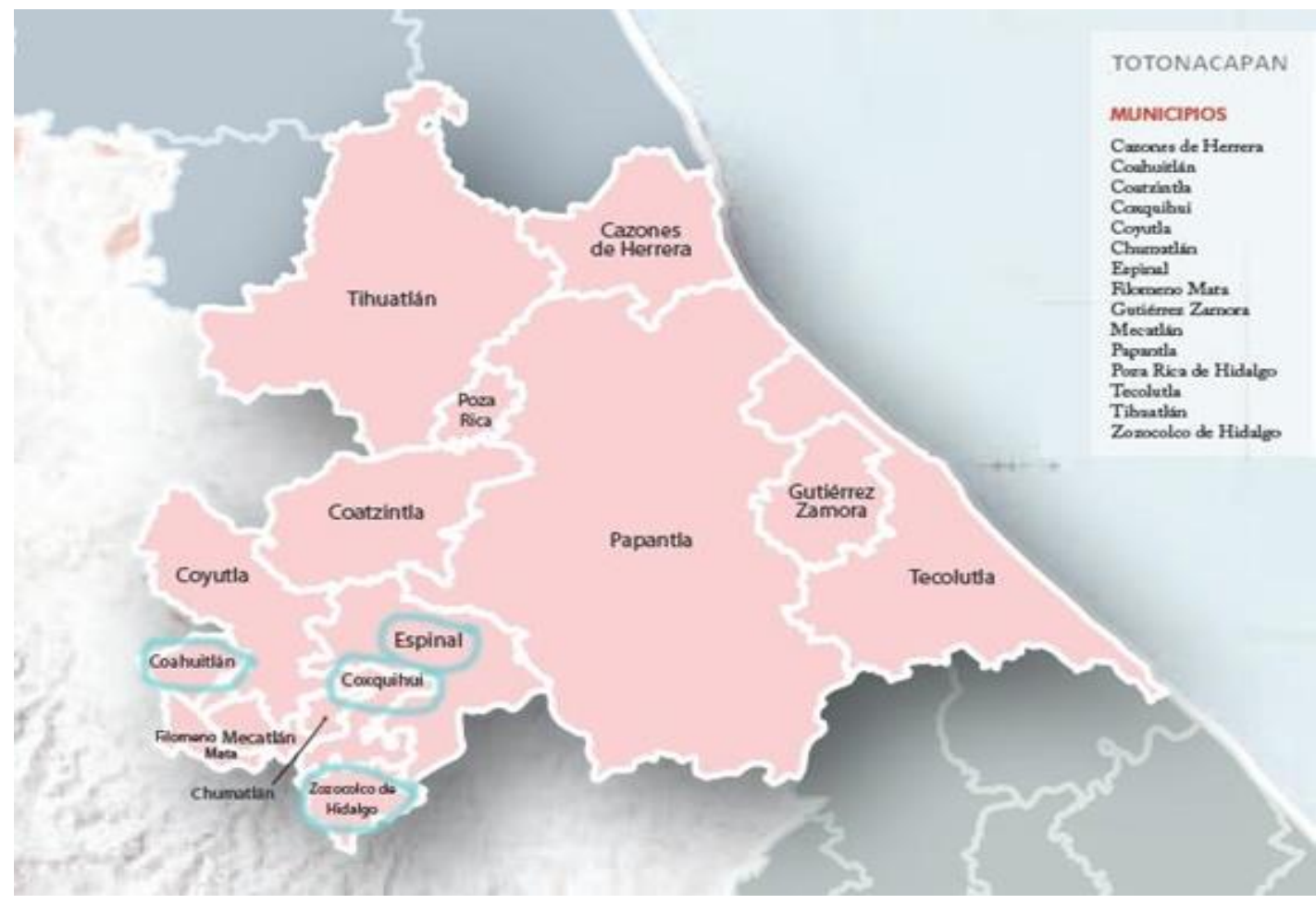

Fonte: Vídeo Tuku wan mi naku. 
Figura 9. Ônibus que nos levava para outros municípios e a saída com alunos com pau de arara

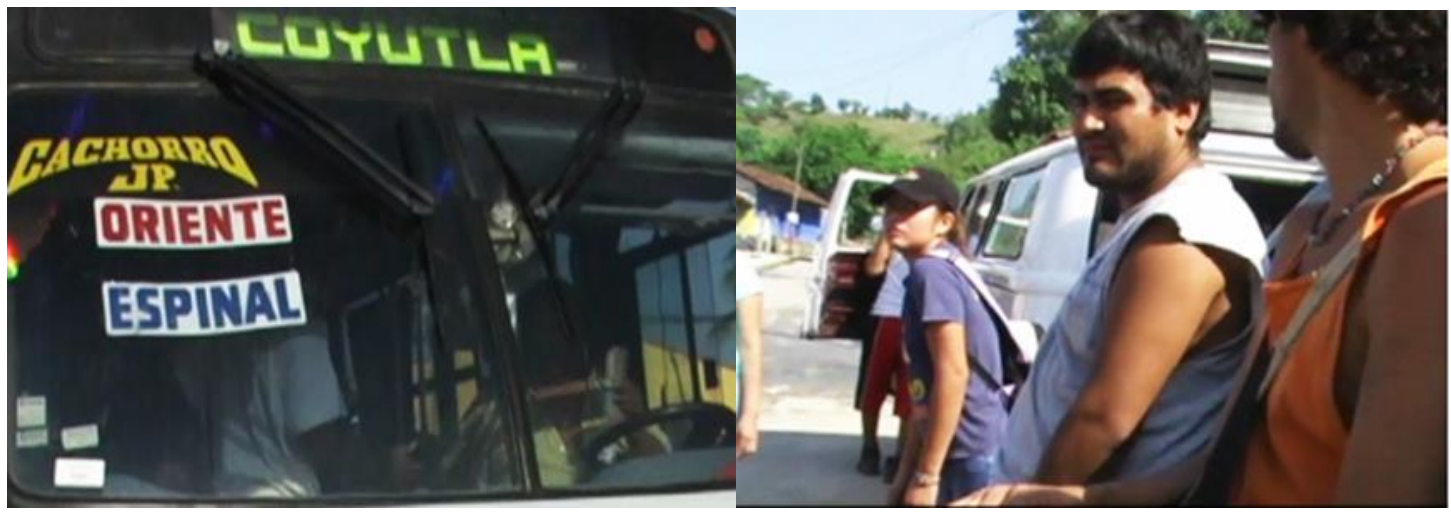

Fonte: $\mathrm{O}$ autor.

Figura 10. Alunos da Sede Totonacapan

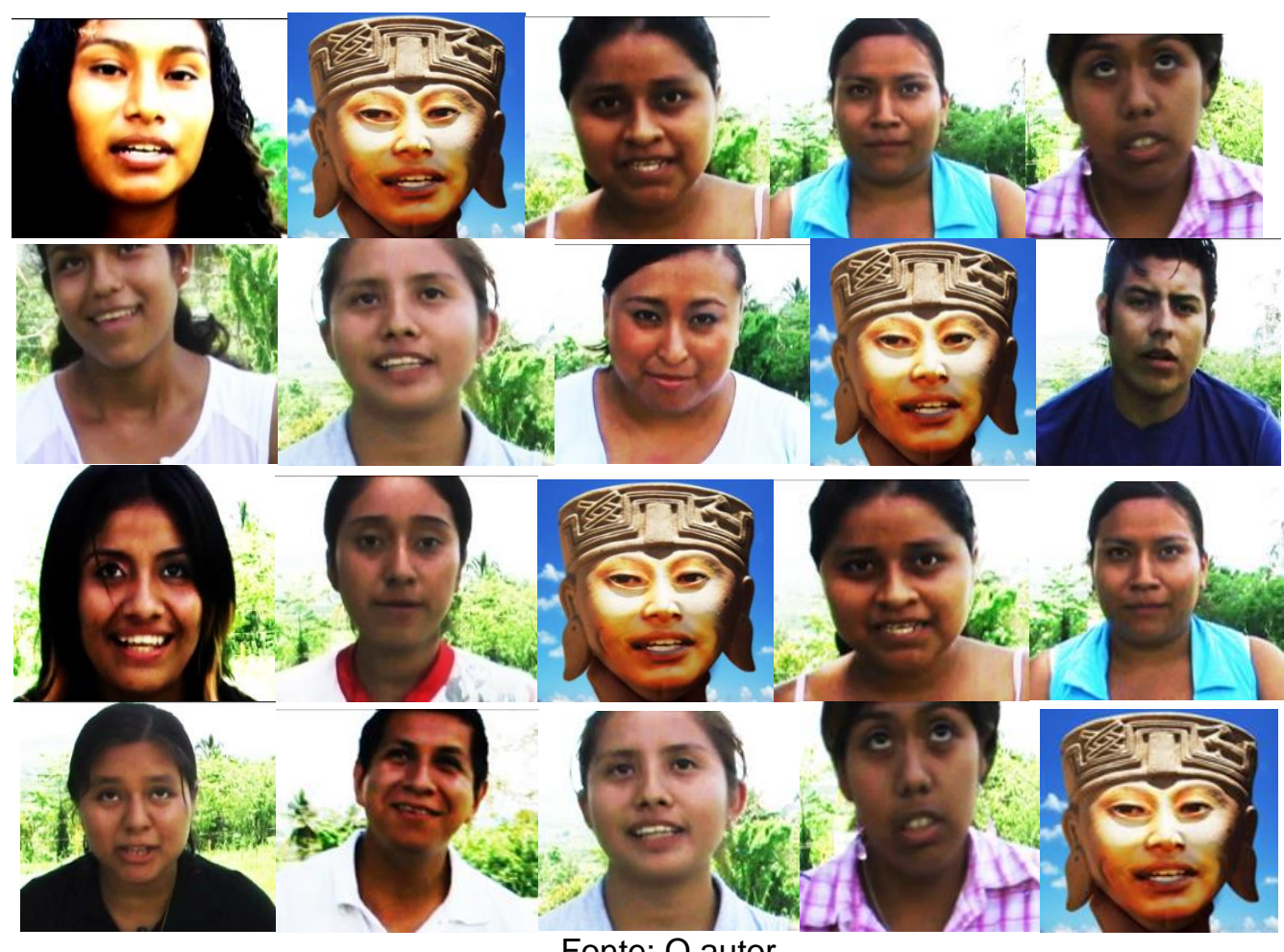

Fonte: $\mathrm{O}$ autor.

A cultura totonaca é reconhecida pela sua expressão artística variada. São exímios poetas, danzantes, músicos e escultores. Uma das características culturais mais marcantes da cultura milenária totonaca são as obras em cerâmica onde aparecem rostos sorridentes. 
Figura 11. Máscaras totonacas

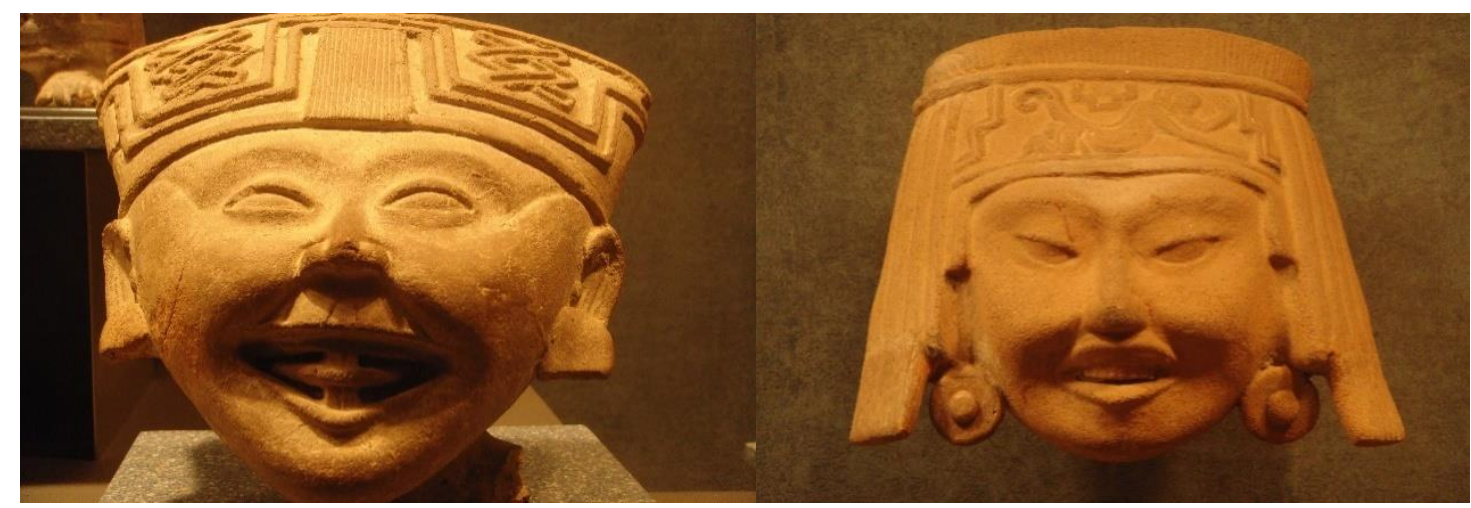

Fonte: Museu de Antropologia de XAlapa.

\section{Coahuitlán}

O vídeo Tuku wan mi naku? aborda o patrimônio de três comunidades específcas: Coahuitlán, Zozocolco e Coxiquihui. Passamos também por Coyutla, mas somente como conexão para se chegar a Coahuitlán. Esta última comunidade não morava nenhum de nossos alunos, mas alguns deles já haviam estado lá antes para realizarem pesquisas, e Ihes havia chamado muito a atenção de como as tradições e a língua totonaca se mantinha bastante preservada. Coahuitlán está no alto de uma serra, bastante isolada, ao redor de bosques, rios e cachoeira. Chama logo a atenção como que as mulheres se vestem. Neste povoado tem-se a tradição da confecção personalizada dos trajes femininos chamados de quexquemene. A cada faixa etária a mulher veste um traje específico e é muito comum que se encontrem artesãs especializadas na confecção deste traje. Em suas roupas são tecidas as flores que compõem a paisagem natural da região.

Figura 12. Imagens de senhoras produzindo e vestindo trajestradicionais em Coahuitlán

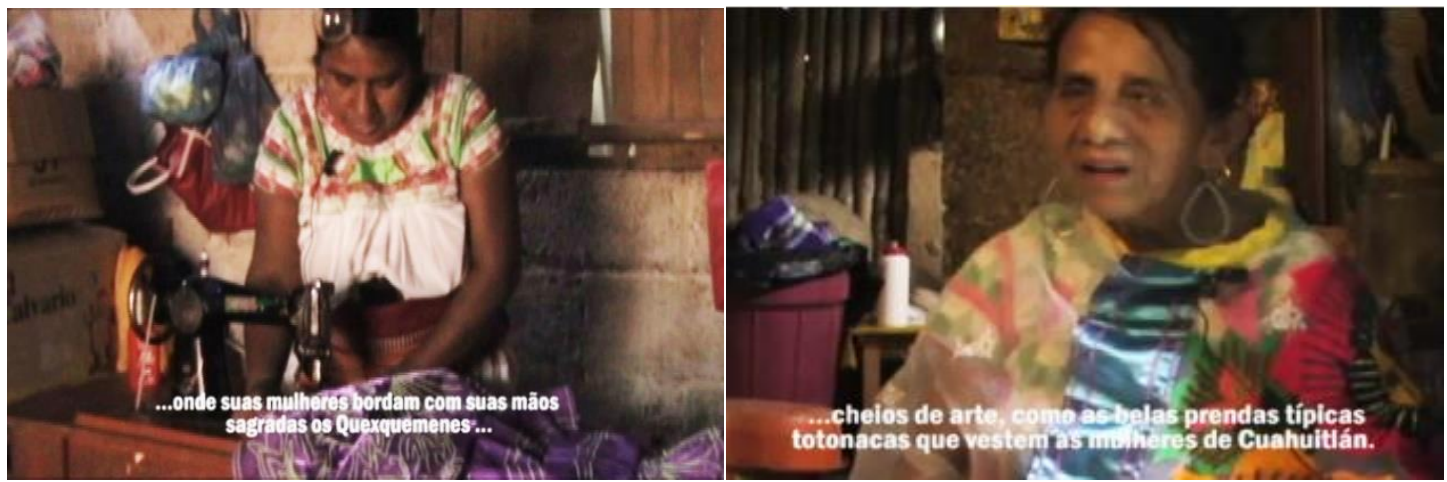

Fonte: $\mathrm{O}$ autor. 
Figura 13. Imagem de mulher totonaca entrevistada pelos alunos

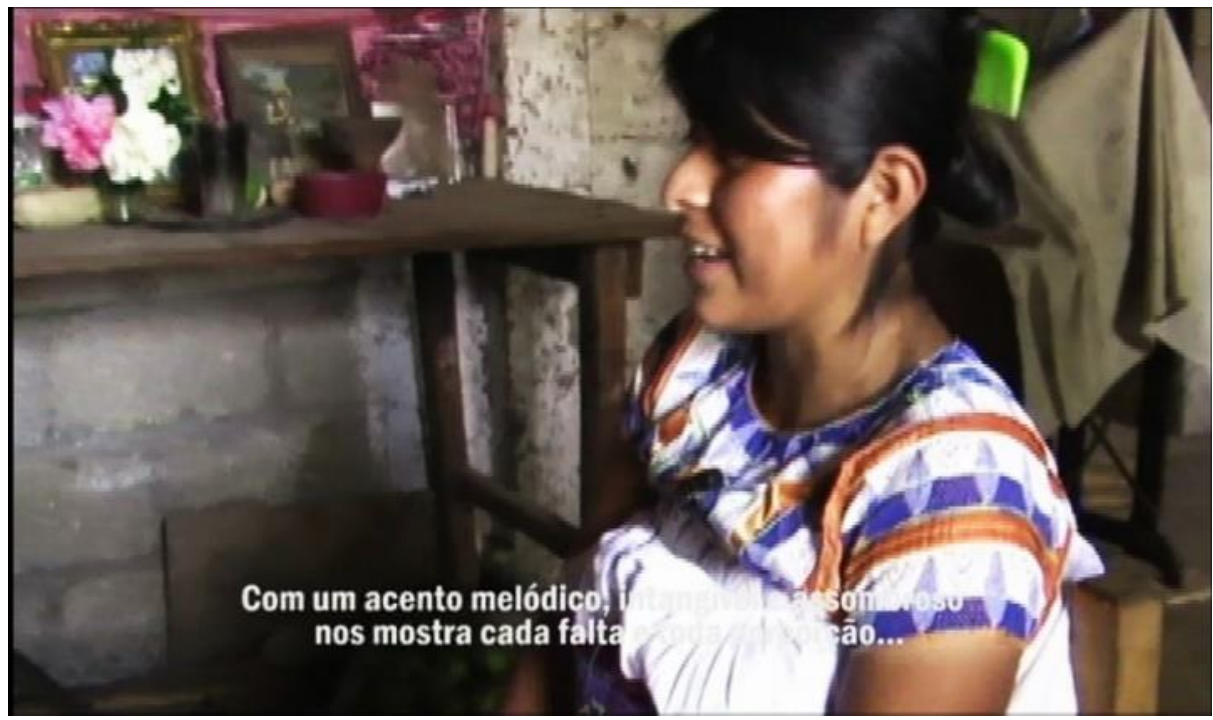

Fonte: $\mathrm{O}$ autor.

Alguns de nossos alunos totonacos, que por saberem falar e entender a língua totonaca, nos diziam que os moradores desta comunidade tinham uma doçura melódica enorme no modo de se comunicar, o que chamava muito a atenção dos alunos. Por mais que a maioria de nossos alunos fossem originários da cultura totonaca, nesta região somente a minoria falava a língua. É comum nas famílias indígenas veracruzanas, não só as famílias totonacas, que os avós falem a língua originária e que muito poucos falem o espanhol, apesar de compreenderem o básico. Já os pais de nossos alunos, em sua formação escolar, foram obrigados em sua juventude a aprender o espanhol, o que os fizeram bilíngues. No entanto, essa geração de nossos alunos, a minoria fala a língua original. Alguns entendem, mas não conseguem se comunicar pela fala. Seguramente esta era uma das preocupações da direção da Universidad Veracruzana Intercultural, atuar também nesta direção, do fortalecimento das línguas originárias.

Outra área que a UVI direciona suas atividades junto aos estudantes é a de Línguas, levando aos estudantes cursos que dão a fundamentação básica das línguas originárias das culturas que se encontram em cada sede. É um curso obrigatório para todos os alunos. Uma forma de que todos reconheçam a importância que a língua originária tem na manutenção das tradições e para o conhecimento das cosmovisões indígenas. Além das línguas originárias a UVI também oferece cursos de francês e inglês. Como também reforço para o espanhol. $O$ que demonstra a direção do pensamento que estimula o encontro e o reconhecimento com as raízes locais mas sem deixar de preparar o alunado para conhecer outras culturas além das regionais. A UVI promove alguns eventos durante o ano letivo para que também os alunos de suas distintas sedes possam se conhecer. São momentos de muita troca e aprendizado. Até mesmo para jovens 
nahuat $/ s^{4}$ que vivem em distintas regiões e estudam em distintas sedes, estes encontros possibilitam o reconhecimento das diferenças entre a mesma cultura.

Em Cahuitlán os estudantes mapearam as artesãs de quexquemene, assim como pesquisaram sobre os efeitos da migração masculina para outros lugares da República e para os Estados Unidos. Outro tema que chamou a atenção foi em torno das práticas de medicina tradicional, tanto da função que as parteiras exercem como o do uso de plantas medicinais e também da utilização dos banhos de suor, mais conhecidos como temazcal em outras regiões.

Figura 14. Senhor Totonaco que foi entrevistado por sua experiência migratória para os EUA -

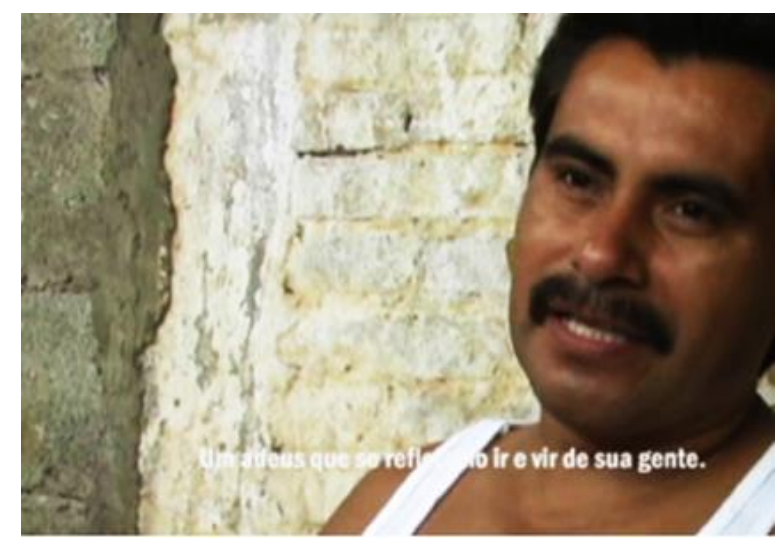

Fonte: O autor.

No entanto, algumas outras informações que eles foram recolhendo e descobrindo em Cahuitlán Ihes fizeram rever alguns traços que são específicos daquela região que fundamentavam as relações sociais naquele pequeno povoado. Em Cahuitlán era comum a prática da venda das filhas mulheres para futuros esposos. Ouvimos alguns casos relatados pela direção da escola que nos deixou a todos muito perplexos, pois até mesmo dentro da própria comunidade, da própria estrutura escolar, tentava-se abordar o tema para que a prática minimizasse. Nossos estudantes ao se deparar com esse tema se comoveram, ainda mais porque quase 80 porcento de nossos alunos eram do sexo feminino. Esta informação foi importante para nosso projeto, já que estávamos mapeando as tradições culturais, tendo como um dos objetivos a revitalização e o reconhecimento delas. No entanto todos nos questionamos sobre a radicalidade da manutenção de algumas delas, por exemplo, esta que havíamos conhecido.

\footnotetext{
${ }^{4}$ Cultura Nahuatl: A cultura nahuatl é a cultura com maior predominância na República mexicana. Conta com mais de um milhão e meio de habitantes que estão espalhados por algumas regiões do país. No mesmo estado de Veracruz habitam distintas comunidades e regiões, e cada uma delas se pode averiguar diferenças em costumes e modos de falar a língua.
} 
A nossa saída a campo para a pequena Coahuitlán marcaria bastante nosso envolvimento com o projeto, tanto em nível de interação grupal como também a nível de compreensão do que era realmente a tarefa de cada um dos alunos como gestor intercultural. Ali se tornava claro que cabiam a eles num futuro próximo trabalharem com questões nem sempre fáceis de serem abordadas nas comunidades. Muitas das alunas nossas traziam reclamações sobre os aspectos machistas que vivenciavam em suas casas. Era tema recorrente também na região do Totonacapan a violência familiar e Coahuitlán nos expunha essa problemática escancaradamente.

\section{Coxiquihui}

Alguns de alunos nossos eram da comunidade de Coxiquihui e para lá também nos encaminhamos para fazer algumas gravações e entrevistas. Uma de nossas alunas, Sofia Gaona, sabendo que ocorreriam as festas patronais nos convidou para conhecer sua comunidade e para ficarmos na casa de sua família. Ficamos dois dias em Coxiquihui e ela nos levou e apresentou muitos lugares e algumas personalidades. Uma delas, a que mais deixaria marcado nosso projeto, foi um caporal ${ }^{5}$ responsável pela Danza de los Quetzales ${ }^{6}$.

Saímos todos juntos em direção a casa deste senhor que vivia no alto de um bosque úmido. O que parecia uma visita que conduiza a um grupo folclórico foi se transformando num grande encontro com uma tradição milenária. Os jovens por mais que já houvessem presenciado a apresentação deste grupo ou de outros que também seguem a tradição da Danza de los Quetzales não sabiam muitas das referências, significados e simbolismos que a Danza remete. E novamente estariamos nos apoiando da ferramenta do audiovisual para traslocar o olhar dos jovens. Seguramente eles não se interessariam por si sós em ir à casa de alguém que conduz uma dança tradicional. Nosso trabalho na UVI em busca de conhecimento e reconhecimento das tradições locais tinha como este objetivo já basante claro junto aos alunos. E eles pouco a pouco, ano a ano faziam seus próprios mapeamentos individualmente. E nós pelo "Proyecto de Difusión del Património" tínhamos o pretexto de registrar e difundir os temas de suas comunidades. Deste modo os jovens tinham em suas mãos um objeto que registraria por toda a história deles o patrimônio de seus lugares.

Por serem eles os portadores dos equipamentos, por serem os próprios jovens totonacos os que iam agendar e fazer os registros junto aos personagens eleitos, as portas que bloqueiam nossa passagem ou gravação pela desconfiança, estava escancarada. Por mais que se sinta em algumas regiões a marca e o rancor

\footnotetext{
${ }^{5}$ Caporal: em várias comunidades rurais está a presença do caporal, pessoa responsável por orientar um grupo que segue alguma tradição cultural. É uma espécie de tutor, que além de transmitir os saberes tradicionais, se responsabiliza pelo cuidado das crianças, quando estas são entregues pelos pais.

${ }^{6}$ Danza de los Quetzales: é uma dança originária da Serra norte do estado de Puebla e também em algumas localidades do Estado de Veracruz.
} 
da colonização europeia, o povo veracruzano em geral é aberto e amável. Mas seguramente que por estarmos juntos com os próprios habitantes do lugar, podíamos adentrar nas histórias com mais imediatismo.

Fomos para a casa do caporal. Tínhamos neste dia somente um equipamento e uma equipe restrita. Já havíamos gravado muito durante o dia e naquela tarde somente algumas jovens mais instigadas subiram comigo para conversar com o senhor. Levávamos câmera, microfone e tripé. Além de muita disposição e sorrisos. O senhor estava em sua humilde casa de barro e bambu a espera de seus discípulos jovens que eram entregues por seus pais para que ele os orientasse na formação como um danzante. Muitas das tradições de dança que encontramos nos interiores de Veracruz são mantidas pelos caporais como um patrimônio que guarda a essência ritual e sagrada herdada pelos ancestrais. Para que alguém possa participar da Danza de los Quetzales a pessoa tem que se submeter a alguns rigorosos comportamentos que o mestre instrui.

Algumas danças e tradições são marcadas por rituais que se não forem seguidos acredita-se que pode recair sobre o indivíduo algumas desgraças. Assim, a figura de um caporal geralmente é uma figura de respeito. No caso deste senhor percebemos de imediato a seriedade como ele assumia a responsabilidade junto aos jovens e seus familiares. E toda a organização da indumentária e o respeito mútuo entre os participantes demonstrava isso. Tivemos a oportunidade de visitar outros caporais, também desta tradição, assim como de outras, como a Danza de los Negritos ${ }^{7}$ e encontramos outros mestres, caporais, que devido a não seriedade de sua função tinham sido desprezados pela comunidade e muitas vezes entregues a problemas como o alcoolismo. As tradições danzantes são muito respeitadas e seguramente naquele dia em Coxiquihui nós estávamos ao lado de um caporal exemplar.

Entramos em sua casa e ele calmamente, entre os jovens que aos poucos eram orientados por ele na organização da indumentária, foi nos contando como iniciou seu processo de formação como caporal e de como recebeu a tradição. Em sua casa havia um altar para o pássaro Quetzal e ele então nos contou a lenda da qual se origina a tradição:

A la danza de los quetzales se le llama porque había el ave aquí cercano...Entonces...el que...primer hizo su primer música... fue un muchacho que vivía con su mama. Vivian en el rancho. Y de ahí...el niño iba andar en el monte. En el monte encontró al pájaro quetzal. Y de ahí...a cada instante, cuando iba, a veces, no siempre, pero cuando iba, encontraba el pájaro quetzal...Y entonces de ahí quiso imitar, o imitó. Para imitarlo corto un tajo(una caña) para hacer una flauta. Entonces por a través de la flauta quiso entonarla. Y lo hizo. A partir de ahí pensó en el latido del corazón del pájaro quetzal, que es

${ }^{7}$ Danza de los Negritos: Dança tradicional de algumas localidades do estado de Veracruz. 
lo que le penetró, no como pensó sino como le penetró en el corazón. Entonces de ahí ya supo cómo se iba a escuchar como un tambor...

Figura 15. Caporal dando entrevista sobre a tradição da Danza de los Quetzales e seus alunos se vestindo.

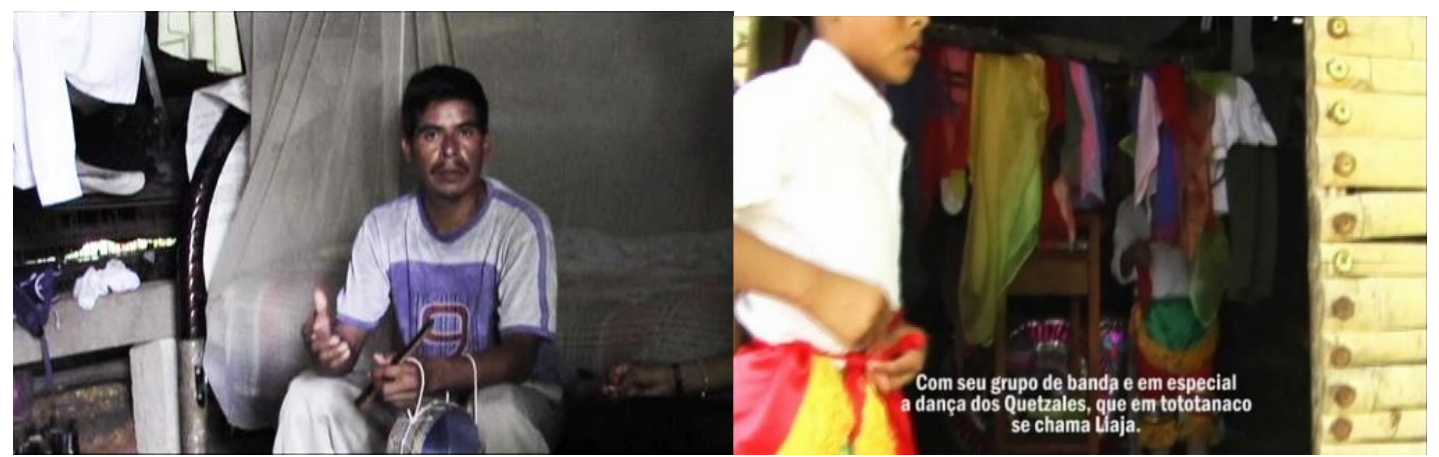

Fonte: O autor.

Figura 16. Imagens dos Danzantes Quetzales
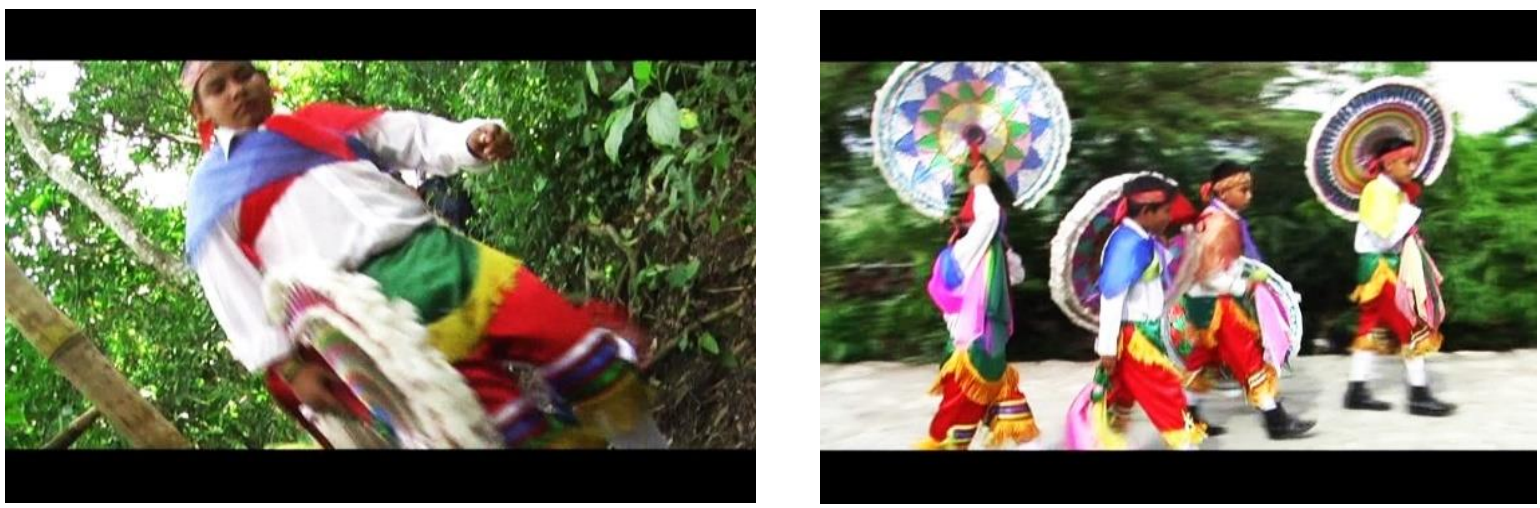

Fonte: $\mathrm{O}$ autor.

A Região do Totonacapan é reconhecida por suas tradições artísticas herdadas pelos totonacas. Algumas manifestações culturais ainda representam de modo muito original este espírito de conexão com as forças mais místicas e sobrenaturais onde os humanos estabelecem um contato íntimo com as plantas, os animais e com as esferas cósmicas. O simbolismo que traz a Danza dos Quetzales e a vivência que tivemos com o este grupo em Coxiquihui nos exemplifica e nos deixa claro o que Bataille (1997) quis dizer quando mencionou sua crítica ao abandono do espírito de animalidade ao qual a cultura ocidental se orienta.

Nossas alunas que subiram ao bosque naquela tarde, ao se colocarem por detrás de uma câmera, ou simplesmente por darem oportunidade de ver a realidade por outro ponto de vista enxergaram e ouviram as histórias do mestre da Danza de los Quetzales de outro modo. Em outro dia quando nos encontramos em sala de 
aula para montarmos um texto que nos serviu para a locução de nosso vídeo, as alunas que vivenciaram o encontro daquele dia expressaram com emoção os significados e símbolos daquela tradição. Era aonde queríamos chegar: que os alunos se apropriassem de suas realidades e conseguissem expressar suas impressões com um espírito crítico e também afetuoso, pois "El penacho representa el pájaro quetzal; el espejo, el alba, la mente limpia; los flejos, los rayos de la luz que guían nuestros caminos" (Sofia Gaona, alumna de la UVI).

O propósito deste trabalho não é fazer uma etnografia das manifestações culturais encontradas, nem sobre as etnias com as quais estivemos trabalhando. Nosso objetivo aqui é tratar sobre o processo criativo e de transmutação do sujeito/coletivo com os quais trabalhamos. O que nos interessa neste trabalho é proporcionar uma reflexão sobre como a produção audiovisual pode promover uma reinterpretação sobre as culturas tradicionais e de como esta arte imersiva e projetiva pode criar novas considerações sobre o papel de um sujeito que adentre com mais sensibilidade nos conhecimentos mais sutis que muitas outras culturas, que não as indo-europeias, produzem e vivem.

Deste modo, quando aqui relato o trabalho de campo junto as comunidades tradicionais veracruzanas é com o intuito de poder levar o leitor a vivenciar a experiência de adentrar no espírito de compreensão multidimensional que muitas comunidades vivenciam no México, muito próximo a outras formas de vida que não somente a humana. Nossa visão artística é fundamentada pela aposta que o diálogo pacífico entre os sujeitos é uma manifestação criativa. Nossa visão artística parte e nasce da experiência vivenciada por uma antropologia mitológica, como Bataille (1997) se refere.

\section{Zozocolco}

Outra comunidade que nossos alunos nos levaram foi Zozocolco. Em nosso roteiro de entrevistas tínhamos o universo agrícola familiar. Uma de nossas alunas queria nos apresentar algumas famílias que naqueles dias estavam colhendo pimenta verde. Era um trabalho comunitário, onde todos se ajudavam. O perfume da pimenta era inebriante. Nem todos os alunos, por mais que morassem em área rural, estavam acostumados ao cotidiano agrícola. Assim, os que tinham mais proximidade com o ambiente, logo se puseram ajudar a separar as pimentas e de forma muito natural a entrevista se foi construindo em língua totonaca com todos sentados no chão conversando. Alguns de nossos alunos, concentrados, gravavam as cenas. Este momento também seria muito lembrado na produção de textos para a locução.

Outra situação bastante marcante foi com outra família que estava produzindo fio de agave. Acompanhar a manufatura que as famílias realizavam com as próprias mãos era para todos um contato mediado por um olhar calmo, distanciado dos preconceitos que o sistema lança aos trabalhos manuais que são realizados pelos 
povos campesinos. E para esta gente ser recebida pelos filhos de parentes ou filhos de vizinhos que estavam na Universidade era uma ocasião de enobrecimento dos saberes milenários tão menosprezados. Era preciso estar do outro lado da câmera, era preciso conhecer aqueles saberes por uma lente que valoriza e compreende o patrimônio e que também sabe olhar com crítica algumas tradições.

Seguramente muitos de nossos alunos, que tinham parentes agricultores ou artesãos, talvez não tinham podido até aquela ocasião reconhecer os saberes de seus pais, ou os saberes de sua comunidade como um saber importante que pertencia ao patrimônio mundial. Ver o cotidiano por detrás de uma câmera, ver o dia a dia habitual ao lado de um colega de Universidade que está estudando o patrimônio de teu lugar com olhos de reconhecimento e compreensão sensível e crítica do sistema era um meio de reconsiderar a própria existência. A oportunidade de estar em repouso numa varanda de uma casa vendo um senhor debulhando a pimenta verde, era permitir que o aroma que se originava no toque das mãos com o fruto entrasse na alma de todos nós. Foi somente parando para escutar e gravar as histórias junto aquela família que conseguimos perceber aquele cheiro. A vida nos grandes centros não permite aos sujeitos vivenciar essa pureza, essa integração com a Natureza. Aquela família em Zozocolco seguramente acompanha sua pimenteira durante todo o ano e sabe esperar a época para realizar a colheita. Eles sabem aguardar o perfume da pimenta. Esse saber, esse conhecimento dos ciclos da natureza, essa apreciação e respeito pelas diversas formas de vida que comungam o desenvolver durante todo o ano não é compreendido pelo sistema industrial, o que não permite que as pessoas ligadas ao meio urbano não tenham possibilidades de valorizar esse singelo saber campesino.

A vida nas comunidades totonacas guarda essa paz e as famílias que vivem nessa região buscam esse equilíbrio que mencionamos antes, que fundamentam os princípios e sentidos do que seja viver em comunidade e comunalidade. A vida humana nas regiões rurais é regida pelo entendimento da interação que o ser humano tem com as outras espécies de vida e entre a vida entre estas outras formas. A sutileza é acessada pelo estado de repouso que podemos vivenciar. $O$ "Proyecto de Difusión del Patrimonio" aproveitava deste momento de pesquisa de campo para repousar as mentes e os olhares nossos e de nossos alunos, buscando criar um produto que pudesse assim também repousar e ampliar a compreensão de outras pessoas que acessassem nossa produção audiovisual. 
Figura 17. Família debulhando pimenta verde

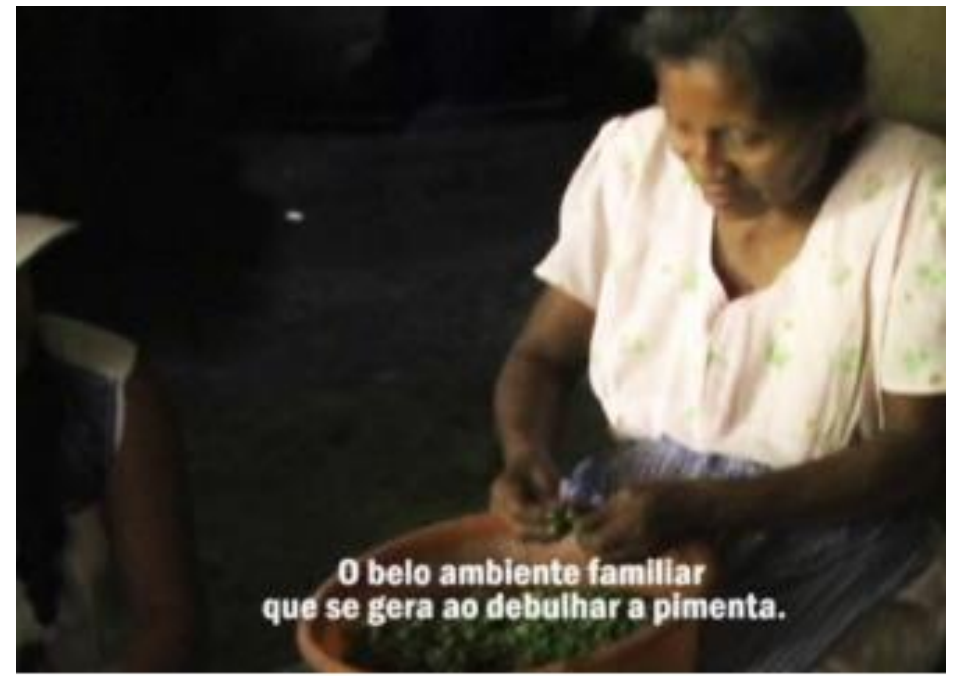

Finalizadas nossas gravações, após caminhar e viajar por tantas comunidades, chegamos a ter em mãos quase vinte horas de vídeo. Voltamos para sala de aula em Espinal. Era momento de analisar as imagens, as gravações, rever as situações, os personagens, os temas. Todo o conteúdo abarcado nos deixava a todos maravilhados com o que havíamos encontrado. Outros colegas da Sede Totonacapan, inclusive Juan Pablo Zebadúa, meu coordenador local, então se davam conta de que poucos professores que já haviam passado por ali tinham realizado tantas saídas a campo. Com todas as saídas um grande logro havia sido poder levar os próprios alunos a conhecer a própria realidade da região. Eles estavam maravilhados com o próprio patrimônio que tinham aos olhos e não viam. Fora necessário ir para detrás de uma câmera. Fora necessário limpar as lentes cotidianas que não permitiam descortinar as vendas que o sistema não deixa e não quer que se veja. Nem tudo o que fora visto era de agrado. Nem tudo eram flores. Haviam muitas dores e dificuldades que foram identificadas. E era aí onde iniciava a labor dos futuros gestores interculturais.

Após revermos todo o material decidimos que nosso documentário teria uma locução de fundo e a sugestão foi então que cada aluno então se apropriasse de um dos temas abordados e que construísse um texto crítico e poético sobre o que havia visto. Após a escrita todos se puseram de frente para a câmera e leram os seus textos, que por fim serviu de narração para o vídeo Tuku wan mi naku. Nos textos produzidos aparecem muitas vezes a palavra "coração". O que responde à pergunta que o próprio título faz: "Que diz teu coração?".

É importante manifestar que a forma de construção do discurso no pensamento pré-hispânico é muito mais estético, etimologicamente falando. Ele constrói uma linguagem que tem como objetivo central fazer sentir mais que entender o que se expressa. O pensamento pré-colombiano constrói uma linguagem 
que possa ser apreendida de forma afetiva e cognitiva sempre relacionando o indivíduo com o seu entorno. Tendo em conta isso torna-se claro porque entre os totonacos o comprimento diário é para se saber o que diz o coração da outra pessoa.

Fora dos âmbitos técnicos, a estruturação, a conservação e a transmissão do saber indígena, se realiza, sem dúvida, mediante a palavra, mas também por através das danças, dos gestos, das roupas, da música, das imagens, dos sabores e aromas, sempre oferecendo componentes para que os cinco sentidos possam receber as informações emitidas como bem expressou o especialista em língua nahuatl, Patrick Johansson (2005, p. 522), em suas análises sobre o sentido e os sentidos da linguagem pré-colombiana:

\begin{abstract}
A diferencia del conocimiento de corte occidental heredado de la mayéutica helénica, el saber indígena prehispánico, necessariamente objetivante como cualquier cognición humana, buscaba sin embargo una aprehensión sensible del objeto por conocer. Buscaba "comulgar" afectivamente con dicho objeto para lograr su aprehensión plena.
\end{abstract}

Fechamos minha primeira estadia na Região do Totonacapan com todos os alunos e professores querendo que eu estendesse minha estância por lá. Era como se eu tivesse recolhido as lenhas para acender a fogueira, que tivéssemos plantados as sementes e que elas já brotavam do solo. Nós havíamos atiçado o coração dos jovens para que eles então iniciassem obras mais aprofundadas, que transpusessem para programas de rádio, para programas de TV. Volto para Xalapa bastante animado com o resultado obtido. Volto com a solicitação de que permanecesse na Região.

\title{
REFERÊNCIAS
}

BATAILLE, Georges. El ojo pineal. Trad. Manuel Arranz. Valencia: Pre-textos, 1997.

DIETZ, Gunther. La experiencia de la Universidad Veracruzana Intercultural. In: MATO, Daniel Mato (coord.). Diversidad cultural e interculturalidad en educación superior.

Experiencias en América Latina. Caracas: IESALC-UNESCO, 2008.

Multiculturalismo, interculturalidad y educación: una aproximación antropológica. Granada: Editorial de la Universidad de Granada, 2003.

DUSSEL, Enrique. 1492: o encobrimento do outro: a origem do mito da modernidade. Comunicação \& política, n.S., v.VII, n.2, 1993.

ELIADE, M. O Sagrado e o Profano: a Essência das Religiões. Tradução Rogério Fernandes. São Paulo: Martins Fontes, 1992. 
FOURNET-BETANCOUT. Raul. Questões de método para uma filosofia intercultural a partir da Ibero-América. São Leopoldo: UISINOS, 1994.

FREIRE, Paulo. Pedagogia do Oprimido. 17. ed. Rio de Janeiro: Paz e Terra, 1987.

JOHANSSON, Patrick. El sentido y los sentidos en la oralidad náhuatl prehispánica. Acta Poetica, Vol. 26, n. 1, 2005.

LENKENDORF, Carlos. Los hombres verdaderos: voces y testimonios tojolabales. México: Siglo XXI, 2008.

Nosotros, otra realidad. Comunicação \& Política. Vol. VII, n. 02, 2000.

LEÓN-PORTILLA, M. La filosofía náhuatl. Cidade do México: UNAM, 1983.

NAVA-VITE, Rafael. Lucha y riqueza cultural de un pueblo nahua de la Huasteca. Tesis de Licenciatura, Sociología de la Universidad Veracruzana, Xalapa, 2000.

RICOEUR, Paul. A identidade narrativa e o problema da identidade pessoal. Trad. Carlos João Correia. Arquipélago, n. 7, p. 177-194, 2000.

. Tempo e narrativa. Trad. Roberto Leal Ferreira. Campinas: Papirus, 1997.

O si mesmo como um outro. Trad. Lucy Moreira César. Campinas: Papirus, 1991.

SAHAGÚN FRAY, Bernardino. Historia general de las cosas de Nueva España. Porrúa: Ángel Ma. Garibay, 1975.

SANDSTROM, Alan R. Ecología cultural, religión panteísta y modelo cognitivo del medio ambiente entre los nahuas del norte de Veracruz, México. EspacioTiempo:

Revista Latinoamericana de Ciencias Sociales y Humanidades, Universidad Autónoma de San Luis Potosí. Año1, Núm., 1, primavera-Verano 2008, p. 42-55. 